\title{
CMEARTICLE
}

\section{Current status of functional gastrointestinal evaluation in clinical practice}

Daphne $\underline{\text { Ang }}{ }^{1}$, MBBS, FRCP, Kwong Ming $\underline{\text { Fock }}^{1}$, MBBS, FRCP, Ngai Moh $\underline{\text { Law }}^{1}$, MBBS, FRCP, Tiing Leong $\underline{\text { Ang }}{ }^{1}$, MBBS, FRCP

\begin{abstract}
Neurogastroenterology and motility disorders of the gastrointestinal (GI) tract encompass a broad spectrum of diseases involving the GI tract and central nervous system. They have varied pathophysiology, clinical presentation and management, and make up a substantial proportion of outpatient clinic visits. Typically, patients experience persistent symptoms referable to the Gl tract despite normal endoscopic and radiologic findings. An appropriate evaluation is thus important in the patient's care. Advances in technology and understanding of the disease pathophysiology have provided better insight into the physiological basis of disease and a more rational approach to patient management. While technological advances serve to explain patients' persistent symptoms, they should be balanced against the costs of diagnostic tests. This review highlights the GI investigative modalities employed to evaluate patients with persistent Gl symptoms in the absence of a structural lesion, with particular emphasis on investigative modalities available locally and the clinical impact of such tools.
\end{abstract}

Keywords: functional gastrointestinal disorders, neurogastroenterology

\section{INTRODUCTION}

\section{GI motility disorders or functional GI disorders}

Patients who present with symptoms suggestive of a disturbance of the gastrointestinal (GI) tract often undergo conventional diagnostic investigations, including endoscopy, radiological imaging and biochemical tests, in order to identify the cause of the symptoms. In the absence of any abnormality, the patient's condition is regarded as 'functional' as opposed to 'organic' in nature. ${ }^{(1)}$ While Gl motility was previously broadly regarded as a disorder of motor function in the Gl tract, we are now more aware of the sensory function of the gut and the complexity of brain-gut interactions in contributing to the symptom complex. The terminology used in functional GI disorders can be confusing. 'Neurogastroenterology'(2) refers to the study of gastrointestinal muscle and nerve, their regulation, as well as their integration with gastrointestinal function, the central nervous system (CNS) and neuroendocrine system. ${ }^{(3)}$ The term 'motility' refers to the motor activity of the digestive tract, including the study of swallowing, gastric emptying, small bowel and colonic transit, and anorectal function. 'Neurogastroenterology and motility disorders' is a broader term encompassing the organ systems that result in the symptom complex experienced by patients. ${ }^{(4)}$ These include the CNS, which contributes to the sensory and motor control of the GI tract, and the enteric nervous and smooth muscles of the Gl tract. ${ }^{(4)}$

Neurogastroenterology and motility disorders can be broadly divided into two groups - functional GI disorders (FGIDs) and GI motility disorders. In the absence of anatomical and biochemical abnormalities, patients who complain of symptoms related to the $\mathrm{Gl}$ tract that are characterised by visceral hypersensitivity are regarded as having FGIDs. On the other hand, GI motility disorders are attributed to underlying neuromuscular pathology, and are characterised by a distinct and measurable alteration of motor function; they generally refer to diseases of GI transit and/or sphincteric function. However both groups are often regarded as 'functional', as they typically do not manifest any abnormalities on conventional endoscopy and radiological imaging, and hence, the two terminologies are frequently used interchangeably. Both FGIDs and GI motility disorders share many similar symptoms and may manifest impaired Gl physiology. ${ }^{(1,5)}$ Alterations in both motility and sensitivity are believed to be important in symptom generation, resulting in overlapping symptoms in both groups.

FGIDs and GI motility disorders represent an emerging field in Asia, and have gradually attracted increased interest in recent years. The growth in interest is in tandem with the rapid development in research and technological advances, especially in the diagnostic armamentarium, leading to a better understanding of the underlying pathophysiology of these conditions. This has resulted in enhanced patient care in this difficult-to-treat patient population. Both FGIDs and GI motility disorders can affect any region of the GI tract and present with symptoms attributed to a disturbance of gut transit or visceral hypersensitivity. Within the oesophagus, motility disorders include achalasia, scleroderma, hypertensive lower oesophageal sphincter, gastroesophageal reflux disease (GERD) and diffuse oesophageal spasm. Functional dysphagia, functional heartburn and functional chest pain are the commonly encountered oesophageal FGIDs. Gastroparesis is the most frequently encountered motility disorder of the stomach, while functional dyspepsia (FD) is the cardinal FGID arising from the stomach. In the colon and rectum, colonic inertia and Hirschsprung's disease are organic motility disorders, whereas irritable bowel syndrome (IBS) is considered an FGID. Table I illustrates the classification scheme used for neurogastroenterology and motility disorders, based on our current understanding of the neuroanatomical level 
Table I. Neurogastroenterology and motility disorders. ${ }^{(4)}$

\begin{tabular}{|c|c|c|c|c|}
\hline Location & Evidence of GI dysmotility & $\begin{array}{l}\text { Both motor and sensory } \\
\text { dysfunctions }\end{array}$ & Primarily sensory & $\begin{array}{l}\text { Primarily CNS } \\
\text { processing }\end{array}$ \\
\hline \multirow[t]{2}{*}{ Oesophagus } & Achalasia & Diffuse oesophageal spasm & Functional heartburn & Globus \\
\hline & Hypotensive LES-GERD & Hypertensive LES & & \\
\hline \multirow[t]{4}{*}{ Stomach } & Gastroparesis & Dumping syndrome & Functional dyspepsia & \\
\hline & Tachygastria & Cyclic vomiting syndrome & Functional nausea & \\
\hline & Scleroderma & Rumination syndrome & & \\
\hline & & Belching disorders & & \\
\hline \multirow[t]{2}{*}{ Biliary disorders } & Gallbladder dysmotility & & & \\
\hline & Sphincter of Oddi dysfunction & & & \\
\hline \multirow[t]{3}{*}{$\begin{array}{l}\text { Intestine and } \\
\text { colon }\end{array}$} & $\begin{array}{l}\text { Chronic idiopathic intestinal } \\
\text { pseudo-obstruction }\end{array}$ & Irritable bowel syndrome & Functional bloating & $\begin{array}{l}\text { Functional } \\
\text { abdominal pain }\end{array}$ \\
\hline & Scleroderma & Functional diarrhoea & & \\
\hline & & Functional constipation & & \\
\hline \multirow[t]{3}{*}{ Anorectal } & Hirschsprung's disease & Functional constipation & Functional proctalgia & \\
\hline & Pelvic floor dyssynergia & Functional anorectal pain & & \\
\hline & & Functional defaecation disorders & & \\
\hline
\end{tabular}

CNS: central nervous system; GERD: gastroesophageal reflux disease; GI: gastrointestinal; LES: lower oesophageal sphincter

at which the dysfunction can be recognised. The Rome process categorised the various forms of FGIDs according to the part of the Gl tract from which the symptoms originate. ${ }^{(1)}$ Definitions have been proposed for functional oesophageal disorders, functional gastroduodenal disorders and functional bowel disorders, among others (Table II). ${ }^{(6-11)}$

Motility of the Gl tract includes the phenomena of contractile activity, tone, compliance, flow and transit. Sensitivity of the GI tract is intimately related to motility. A range of techniques, both invasive and noninvasive, can be applied to evaluate enteric sensorimotor function in health and disease. Despite the clear pathophysiological distinction between GI motility disorders and FGIDs, symptoms generated by disturbances of gut transit (motility disorders) or visceral sensation (FGIDs) often overlap; hence, it may be extremely difficult to distinguish between the two groups. Patients often suffer from severe Gl symptoms, which may mimic structural lesions and lead to significant impairment in the quality of life. ${ }^{(12)}$ Ultimately, diagnostic tests performed for functional Gl evaluation are useful in allowing the clinician to evaluate the patient's symptoms and facilitate a rational approach to patient management.

\section{Yield of functional GI studies}

Endoscopy and radiological imaging are first-line investigations. If these investigations do not yield any abnormalities, the performance of more diagnostic tests allows the clinician to further characterise symptoms. Performance characteristics of an ideal clinical investigative modality include: (a) it yields a high diagnostic specificity (i.e. the results of the diagnostic test lead to a specific diagnosis); (b) it provides an explanation for the cause of the patients' symptoms; (c) it determines the choice of therapy; and (d) it predicts a response to therapy. ${ }^{(13)}$ In this review, we highlight the investigative modalities employed in the evaluation of patients with persistent Gl symptoms despite negative endoscopic and imaging findings, with particular emphasis on facilities that are available locally and the clinical impact of such investigative tools.

\section{EVALUATION OF OESOPHAGEAL FUNCTION}

Disorders of the oesophagus are mainly due to alterations in neuromuscular function. Significant advances have been made in the understanding of the complex pathophysiology of oesophageal disorders. This is fuelled by the development of various diagnostic modalities that are readily available in most institutions in Singapore. Oesophageal manometry is useful in the diagnosis and classification of oesophageal motility disorders. ${ }^{(14)}$ In the early days, oesophageal manometry was performed with the conventional water-perfused catheter system with 4-8 sensors. Pioneering work by Clouse and Staiano ${ }^{(15)}$ led to the use of pressure topography to analyse and view manometric data from standard line plots to provide information about oesophageal peristalsis, which was not appreciated from conventional line tracings (Fig. 1a). Technological advances ${ }^{(16)}$ have led to the development of the oesophageal high-resolution manometry (HRM) system, which involves the use of a catheter with up to 36 closely spaced pressure sensors set $1 \mathrm{~cm}$ apart. Oesophageal HRM, when combined with pressure topography plots (Figs. 1b \& 2), enables pressure amplitude to be transformed into spectral colours, with isobaric conditions indicated by similar coloured regions (Fig. 3). High-resolution oesophageal pressure topography (HREPT) ${ }^{(16)}$ has replaced the conventional oesophageal manometry system previously used in Singapore. The use of oesophageal HRM allows for the diagnosis of oesophageal motility disorders based on the Chicago Classification. ${ }^{(17)}$ The most obvious impact of HREPT in clinical practice is the improvement in sensitivity of manometry 
Table II. Summary of the Rome III classification of functional G disorders. ${ }^{(6-11)}$

\begin{tabular}{|c|c|}
\hline GI disorder & Rome III classification \\
\hline \multirow{4}{*}{$\begin{array}{l}\text { A. Functional } \\
\text { oesophageal disorders }\end{array}$} & A1. Functional heartburn \\
\hline & $\begin{array}{l}\text { A2. Functional chest pain of presumed } \\
\text { oesophageal origin }\end{array}$ \\
\hline & A3. Functional dysphagia \\
\hline & A4. Globus \\
\hline \multirow[t]{3}{*}{$\begin{array}{l}\text { B. Functional } \\
\text { gastroduodenal } \\
\text { disorders }\end{array}$} & $\begin{array}{l}\text { B1. Functional Dyspepsia } \\
\text { B1a. Postprandial distress syndrome } \\
\text { B1b. Epigastric pain syndrome }\end{array}$ \\
\hline & $\begin{array}{l}\text { B2. Belching disorders } \\
\text { B2a. Aerophagia } \\
\text { B2b. Unspecified excessive belching }\end{array}$ \\
\hline & $\begin{array}{l}\text { B3. Nausea and vomiting syndromes } \\
\text { B3a. Chronic idiopathic nausea } \\
\text { B3b. Functional vomiting } \\
\text { B3c. Cyclic vomiting syndrome }\end{array}$ \\
\hline \multirow{5}{*}{$\begin{array}{l}\text { C. Functional bowel } \\
\text { disorders }\end{array}$} & C1. Irritable bowel syndrome \\
\hline & C2. Functional bloating \\
\hline & C3. Functional constipation \\
\hline & C4. Functional diarrhoea \\
\hline & $\begin{array}{l}\text { C5. Unspecified functional bowel } \\
\text { disorder }\end{array}$ \\
\hline \multicolumn{2}{|l|}{$\begin{array}{l}\text { D. Functional abdominal } \\
\text { pain syndrome }\end{array}$} \\
\hline \multirow{3}{*}{$\begin{array}{l}\text { E. Functional gallbladder } \\
\text { and sphincter of Oddi } \\
\text { disorders }\end{array}$} & E1. Functional gallbladder dysfunction \\
\hline & $\begin{array}{l}\text { E2. Functional biliary sphincter of Oddi } \\
\text { disorder }\end{array}$ \\
\hline & $\begin{array}{l}\text { E3. Functional pancreatic sphincter of } \\
\text { Oddi disorder }\end{array}$ \\
\hline \multirow{3}{*}{$\begin{array}{l}\text { F. Functional anorectal } \\
\text { disorders }\end{array}$} & F1. Functional faecal incontinence \\
\hline & $\begin{array}{l}\text { F2. Functional anorectal pain } \\
\text { F2a. Chronic proctalgia } \\
\text { F2a1. Levator ani syndrome } \\
\text { F2a2. Unspecified functional } \\
\text { anorectal pain }\end{array}$ \\
\hline & $\begin{array}{l}\text { F3. Functional defaecation disorders } \\
\text { F3a. Dyssynergic defaecation } \\
\text { F3b. Inadequate defaecatory propulsion }\end{array}$ \\
\hline
\end{tabular}

in evaluating oesophagogastric junction relaxation, as well as in the subclassification of achalasia.(8) This subclassification of achalasia is important, as it has been shown to be a prognostic indicator of long-term outcome in achalasic patients. ${ }^{(18,19)}$

Acid reflux (AR) and non-acid reflux (NAR)-related events in the oesophagus continue to be an area of intense research. While GERD used to be easily treated with proton pump inhibitors (PPIs), gastroenterologists are now encountering an increasing number of patients who have a normal endoscopy but continue to have reflux-like symptoms, including heartburn and regurgitation, and who do not respond well to PPIs. In this setting of PPI-refractory symptoms, functional oesophageal tests are useful to guide further management. Unlike the conventional 24-hour nasopharyngeal $\mathrm{pH}$ catheter system (Fig. 4) that is used for evaluation of $\mathrm{AR}$, the Bravo wireless $\mathrm{pH}$ capsule (Fig. 5) allows for a catheter-free measurement of AR over an extended period of 48 hours. ${ }^{(20,21)}$ However, similar to the conventional 24-hour nasopharyngeal catheter system, the Bravo capsule only provides information on acid-related reflux events. To further characterise the $\mathrm{pH}$ and nature of the refluxate, the combined multichannel intraluminal impedance-pH (MII-pH) monitoring system evaluates patients for both AR and NAR events. ${ }^{(22-24)}$ The technical principle of MII-pH technology (Fig. 6) is that impedance is inversely proportional to the electrical conductivity of the material traversing the oesophagus. A liquid refluxate has the highest conductivity and conversely, the lowest impedance value, as opposed to a gaseous refluxate. MII-pH thus provides information on the $\mathrm{pH}$ and nature of the refluxate, i.e. liquid, gaseous, or mixed liquid and gaseous. In addition, it allows us to evaluate the proximal extent of the refluxate, a factor which has been shown to be associated with symptom perception. ${ }^{(25,26)}$ Taken together, MII-pH has allowed for a redefinition of the classification of non-erosive reflux disease, as patients with a positive symptom association for AR and NAR events are regarded as having a hypersensitive oesophagus, whereas patients with a negative symptom association are deemed to have functional heartburn. ${ }^{(27)}$ The management of hypersensitive oesophagus and functional heartburn includes pain modulators and low-dose antidepressants in the appropriate clinical setting.

\section{EVALUATION OF GASTRIC FUNCTION}

Dyspepsia is a symptom complex that is defined as persistent or recurrent abdominal pain or discomfort centred in the upper abdomen. If the symptoms persist for more than three months without an anatomical or a biochemical abnormality, this would fulfil the definition of FD. ${ }^{(7)}$ Many surveys have evaluated the prevalence of dyspepsia in the community, with rates varying depending on the definitions used. The prevalence rate has been estimated to be approximately $15 \% .{ }^{(28)}$ Several pathophysiological mechanisms have been proposed to underlie symptom generation in FD. Gastric symptoms can be attributed to abnormal gastric emptying, impaired gastric accommodation, heightened gastric sensation, or alterations in gastric myoelectrical function and contractility. ${ }^{(29)}$ Investigations in gastric motility are generally pursued only after exclusion of an organic cause and failure to respond to PPIs and prokinetic agents.

\section{Gastric emptying}

Measurement of the rate of gastric emptying is a test that is most frequently used to access gastric function. The gold standard for evaluation of gastric emptying is the gastric scintigraphic study, for which important consensus guidelines are available. ${ }^{(30)}$ The percentage of gastric emptying is measured using scintigraphic images at intervals of up to 4 hours after ingestion of a radioisotope-labelled meal. The gastric residue at 4 hours has been shown to be the most accurate parameter for the detection of delayed gastric emptying, with a sensitivity and specificity of $100 \%$ and $79 \%$, respectively. ${ }^{(30)}$ However, the disadvantages of this method are the need for the use of radioactive labels, high costs and the lack of standardisation of meals across centres. To circumvent exposure to radiation, the ${ }^{13} \mathrm{C}$-octanoate-breath test, an alternative method that has shown good correlation with 

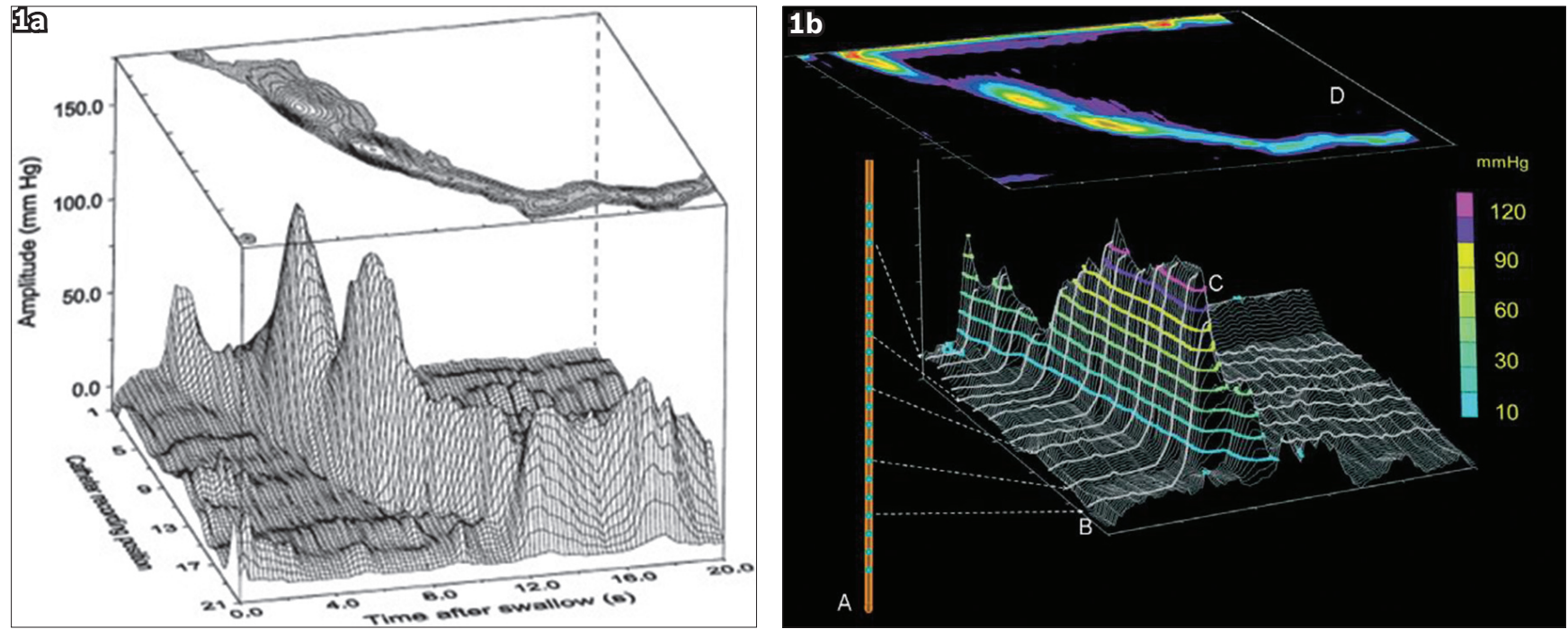

Fig. 1 (a) High-resolution manometry (HRM) from line plots to spatial temporal plots. ${ }^{(15)}$ The $x$-axis represents time, $y$-axis represents the position along the catheter, and z-axis represents pressure recordings. (b) The concept of HRM. Closely spaced recording sensors on an oesophageal motility catheter generate multiple recordings throughout the oesophagus. Dashed arrows point to pressure recordings from individual sensors. Computer software fills in best fit data between the recording sensors spaced $1-\mathrm{cm}$ apart, and colour codes amplitude levels. Finally, the image is smoothed out electronically and displayed as a topographic contour plot, with ' $D$ ' representing the peristaltic sequence when viewed from above. The contour plots are termed Clouse plots in honour of Ray Clouse, who developed HRM (reproduced with permission from Wiley @ Gyawali CP. Neurogastroenterol Motil 2012; 24 (Suppl 1):2-4).

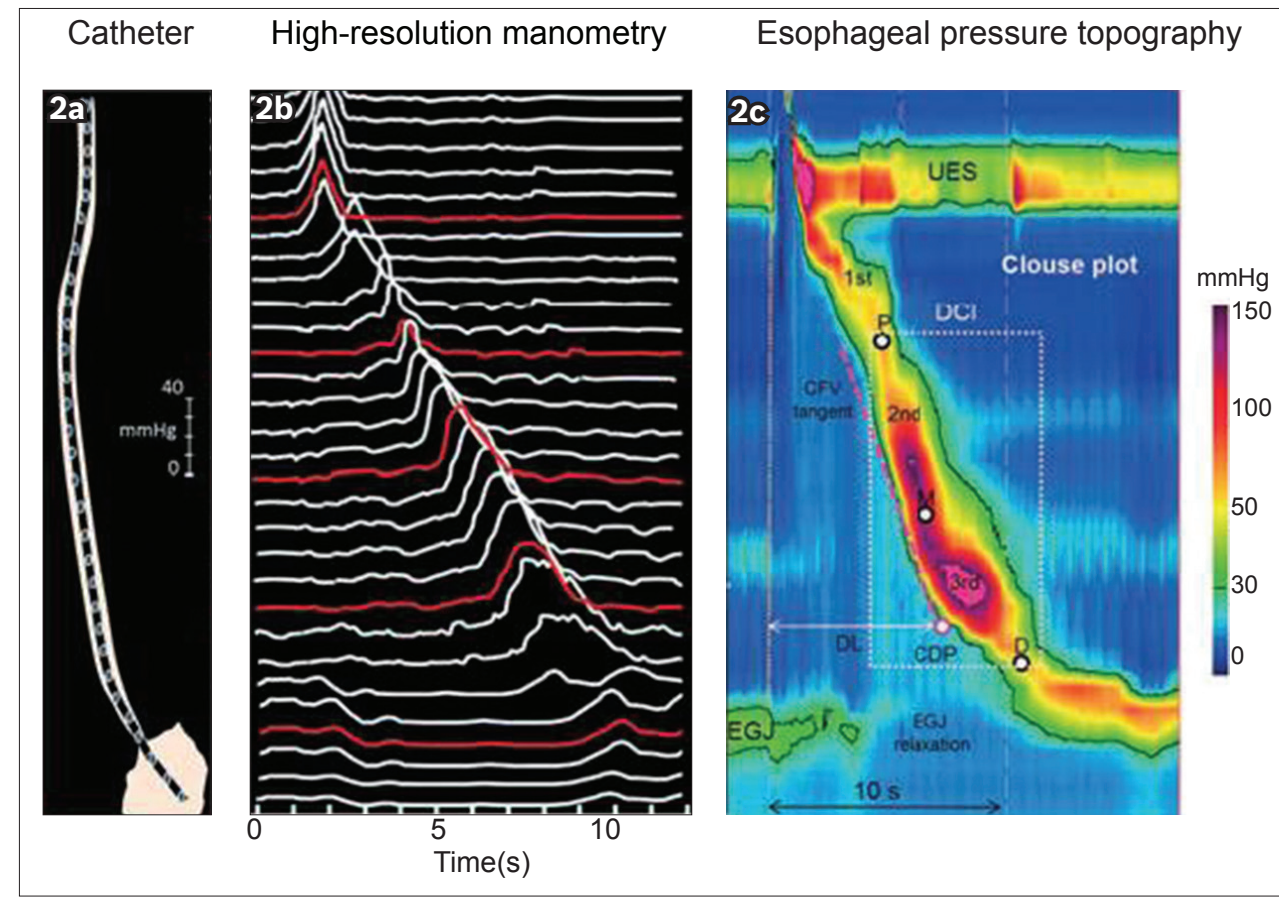

Fig. 2 Distinguishing conventional manometry from high-resolution manometry (HRM) with oesophageal pressure topography. (a) The catheter in this example has 30 pressure sensors spaced $1-\mathrm{cm}$ apart along the length of the catheter. (b) The data output for HRM would be in the form of a line-tracing format providing a measure of contractile strength on a vertical axis. The red lines depict what the conventional manometry spacing would be if the sensors were spaced at 5-cm intervals. (c) Clouse plots: The line tracing format pressure data is converted into pressure topography by converting the pressure signal into a colour. Using an isobaric contour tool to isolate all the pressure above $30 \mathrm{mmHg}$, the anatomic landmarks can be identified: the upper oesophageal sphincter (UES); lower oesophageal sphincter (LES) and oesophago-gastric junction (EGJ) high-pressure zones. There are three distinct segments of contraction along the contractile wave - front separated by three distinct pressure troughs highlighted by $\mathrm{P}$ (proximal or transition zone), M (middle), and D (distal). The start of the swallow is highlighted by the dotted yellow line at the start of UES relaxation, and this is an important temporal landmark in oesophageal pressure topography (EPT) analysis. The contractile deceleration point (CDP) is a time point along the contractile wavefront and signifies a transition from the oesophageal body to LES function. The distal latency is calculated by measuring the time between the start of the UES relaxation and the CDP. Contractile front velocity (CFV) assesses propagation, and is similar to the standard peristaltic velocity, with the caveat that the measurement is confined to the oesophageal body domain between the proximal trough and the CDP. Contractile vigour is calculated differently using EPT: the distal contractile integral (DCI) quantifies the contractile activity within the space time box highlighted by the white dotted box. It calculates the pressure activity above $20 \mathrm{mmHg}$ to exclude artifact and intrabolus pressure, and is presented using a unit of $\mathrm{mmHg}$ cm-s (reproduced with permission from Wiley @ C Gyawali CP, et al. Neurogastroenterol Motil 2013; 25:99-133). 


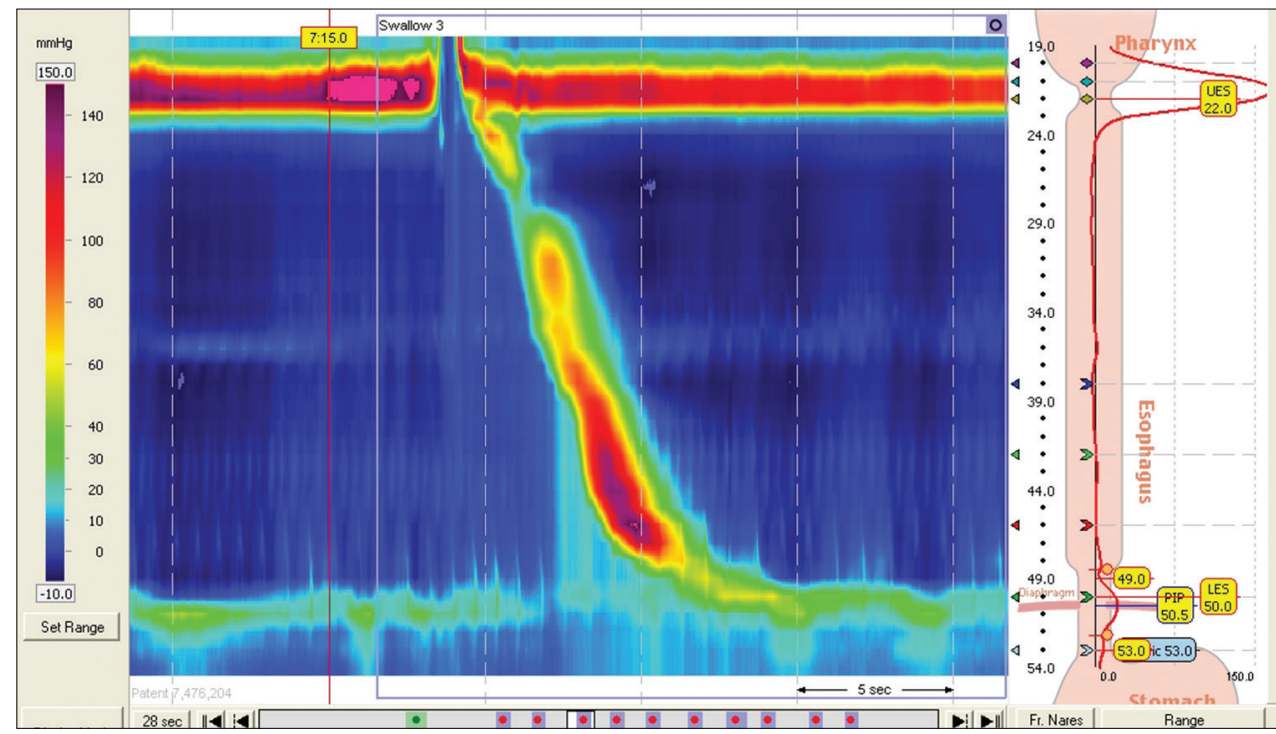

Fig. 3 Example of a HRM tracing illustrating normal peristalsis.

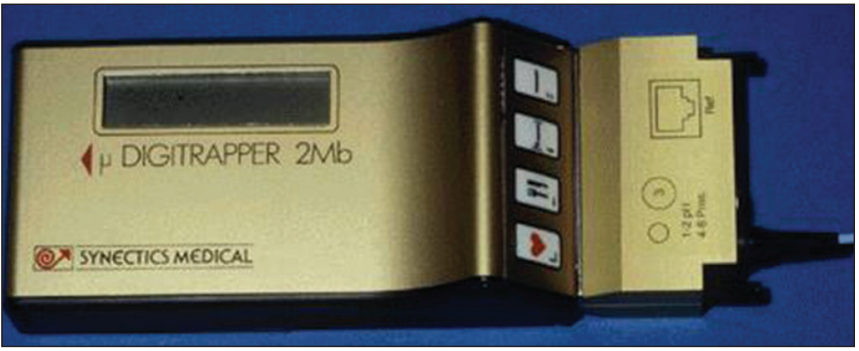

Fig. 4 Photograph shows a conventional 24-hour pH catheter system that measures only acid reflux.

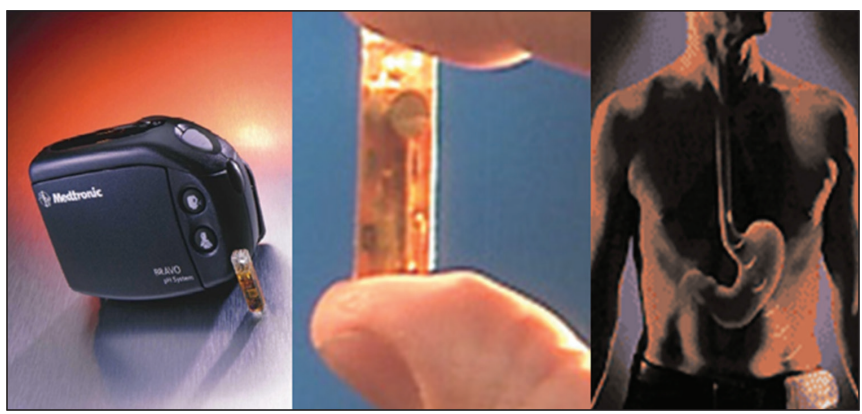

Fig. 5 The wireless $\mathrm{pH}\left(\mathrm{Bravo}^{\mathrm{TM}}\right)$ capsule (Medtronic Inc, Minneapolis, MN, USA) measures $6 \mathrm{~mm} \times 5.5 \mathrm{~mm} \times 25 \mathrm{~mm}$. The capsule attaches to the oesophageal wall and transmits $\mathrm{pH}$ data via radiofrequency signal to a small receiver attached to the patient's belt.

the conventional scintigraphic study, can be used. ${ }^{(31-33)}$ This test employs a standardised meal labelled with ${ }^{13} \mathrm{C}$-octanoic acid. Following gastric emptying, the ${ }^{13} \mathrm{C}$ substrate is absorbed and rapidly metabolised in the liver, generating ${ }^{13} \mathrm{CO}_{2}$. By measuring ${ }^{13} \mathrm{CO}_{2}$ in expired breath samples taken at regular intervals, it is possible to calculate a gastric emptying curve. More recently, the wireless SmartPill ${ }^{\circledR}$ GI Monitoring System (SmartPill Corporation, Buffalo, NY, USA) allows the evaluation of regional and whole gut transit times. Using the wireless SmartPill, gastric emptying is measured as the time interval between ingestion of the capsule and an abrupt increase in $\mathrm{pH}>3 \mathrm{pH}$ units from gastric to baseline.

However, the relationship between gastric emptying and symptom pattern is as yet controversial. ${ }^{(34,35)}$ Studies have not shown a correlation between the severity of delayed emptying and the response to prokinetic therapy. More recently, rapid gastric emptying has been implicated in FD patients. ${ }^{(36,37)}$ The mechanism for this phenomenon has been attributed to enhanced antral contractility, decreased duodenal feedback inhibition and impaired accommodation. ${ }^{(38)}$ Hence, FD symptoms may be attributed to either delayed or rapid gastric emptying. In routine clinical practice, patients who have symptoms suggestive of dysmotility or gastroparesis are often treated empirically with prokinetic drugs, regardless of the results of the gastric emptying test. Dietary measures and somatostatin analogues are, however, rarely used in cases suggestive of rapid gastric emptying, such as in dumping syndromes. Therefore, gastric emptying tests, although not routinely recommended, are useful for patients who continue to experience persistent symptoms despite having received empirical treatment, as this allows the gastroenterologist to further characterise the symptoms and employ more invasive treatment modalities, such as more intense prokinetic therapy or experimental treatment in the appropriate research setting.

\section{Gastric accommodation}

The prevalence of impaired gastric accommodation in patients evaluated for FD is approximately $40 \%{ }^{(39,40)}$ The conventional gold standard for the evaluation of impaired gastric accommodation involves the use of a gastric barostat. This involves the insertion of a double lumen polyvinyl tube with an adherent plastic bag through the mouth into the stomach. The balloon is unfolded by inflation of $500 \mathrm{ml}$ of air and positioned in the proximal stomach by gently withdrawing the tube until slight resistance is felt. The tube is connected to the barostat, allowing for the measurement of changes in gastric tone and sensitivity. In this way, the gastric accommodation response to various interventions can be evaluated. However, impaired gastric accommodation is not specific for dyspepsia, as it may be seen in various conditions, such as FD, diabetic gastropathy, rumination syndromes and post-Nissen fundoplication, as well as in patients with anxiety. In addition, the invasive nature of the gastric barostat and the 

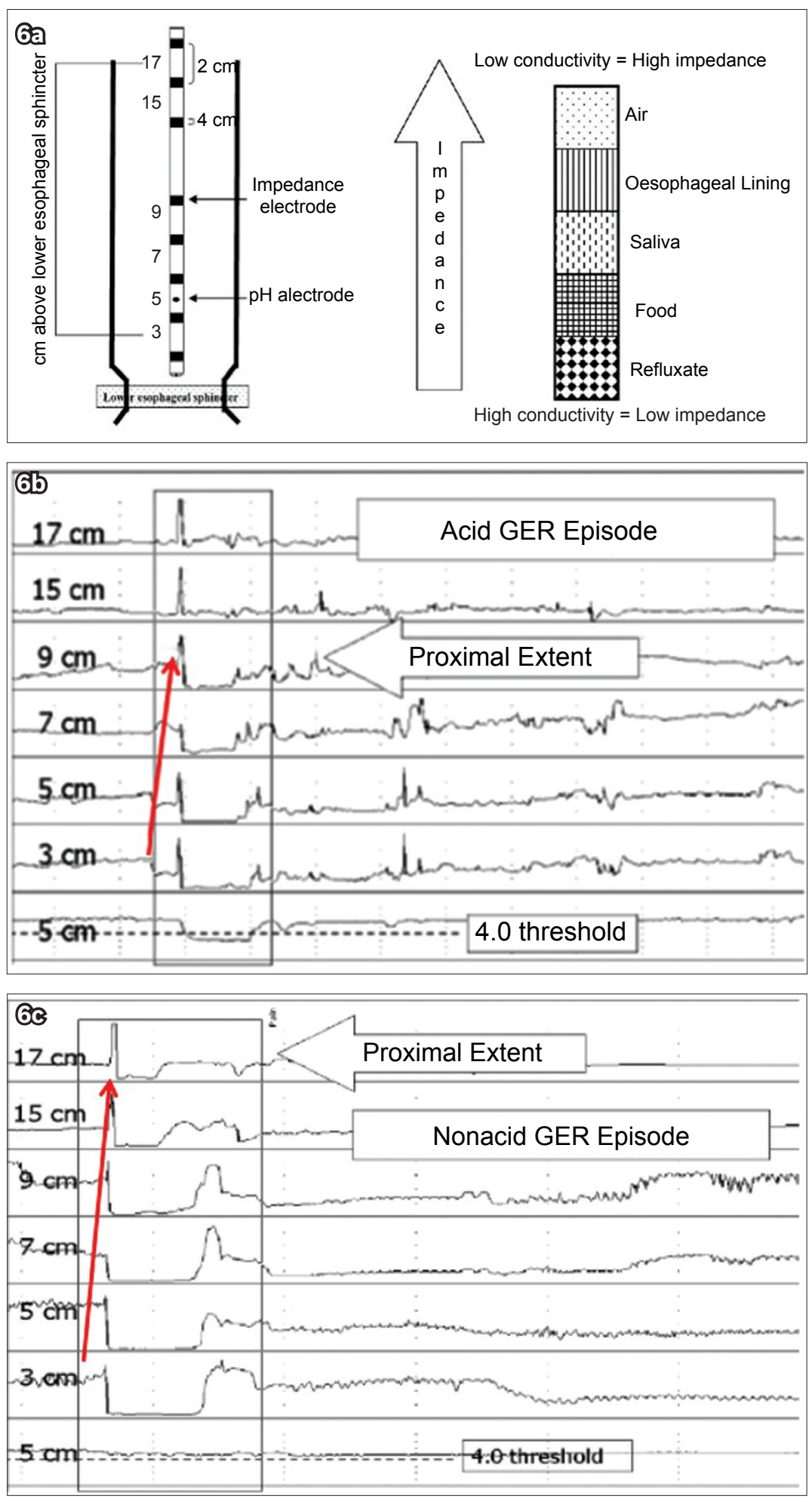

Fig. 6 (a) Diagram illustrates the principles of intraluminal impedance-pH monitoring. In this technique, resistance to an alternating current is measured at multiple sites along the oesophagus. This is performed with a thin catheter mounted with ring electrodes. MII-pH detects the presence of a bolus by means of changes in the conduction between electrodes. Bolus contents that are liquid and mixed have a low impedance, and gas contents have a higher impedance. By using several pairs of electrodes, the detection of bolus movement is possible. The reflux can further be categorised by the $\mathrm{pH}$ electrode into acid $(\mathrm{pH} \leq 4)$ or non acid $(\mathrm{pH}>4)$ (reproduced with permission from Elsevier (c) Savarino V. Dig Liver Dis 2004; 36:565-9). (b) Combined multichannel intraluminal impedance and pH (MII-pH) monitoring. Example of an acid reflux episode. Figure illustrates impedance measuring channels centred at 3, 5, 7, 9, 15 and $17 \mathrm{~cm}$ above the lower esophageal sphincter (LES). MII-pH identifies reflux episodes as rapid decline in intraluminal impedance progressing over time from distal to proximal (arrow). Information from the $\mathrm{pH}$ channel is used to distinguish between acid (nadir $\mathrm{pH}<4$ ) and non-acid (nadir $\mathrm{pH}>4$ ) reflux episodes. (c) Example of a non-acid reflux episode. 
discomfort associated with this investigative modality have limited the performance of this test only to tertiary referral centres within a research setting.

Gastric volume imaging techniques using ultrasonography, ${ }_{(11,42)}$ as well as single-photon emission computed tomography ${ }^{(43)}$ imaging have enabled the quantitative assessment of changes in proximal stomach volume after a meal, with the assumption that any changes in proximal stomach volume after a meal reflect meal-induced gastric accommodation. Gastric magnetic resonance $(M R)$ imaging has been used to measure gastric emptying and to evaluate gastric motor function noninvasively without exposure to radiation. ${ }^{(44)}$ However, the high costs of these modalities and their limited availability have largely restricted their use to research settings.

\section{Electrogastrography}

The electric potentials or slow waves that underlie motor activity in the stomach can be measured with cutaneous electrodes. Electrogastrography (EGG) provides information on the frequency and regularity of the gastric pacemaker activity. ${ }^{(45)}$ Special methodologies are required to acquire, amplify and filter the signals. Gastric dysrhythmias are recognised when the electrical frequency is less than (bradygastria) or more than (tachygastria) 3 cycles per minute. Although the EGG is a noninvasive method of measuring gastric electrical activity, there has been limited correlation between EGG and gastric emptying/contractility. In addition, EGG abnormalities can be induced by non-GI causes. ${ }^{(46}$ Hence, the role of EGG has also primarily been restricted to research settings.

\section{Evaluation of small bowel function}

The time interval between ingestion of a non-absorbable carbohydrate (lactulose) and its arrival in the caecum is the orocaecal transit time, which can be measured using hydrogen excreted in the breath. ${ }^{(47)}$ Although initial breath tests relied on the measurement of labelled $\mathrm{CO}_{2}{ }^{(48)}$ difficulties encountered when correcting for endogenous $\mathrm{CO}_{2}$ had affected the accuracy of these tests. ${ }^{(49)}$ In addition, the process of conjugating substrates with labelled carbon is costly. For these reasons, $\mathrm{CO}_{2}$ had breath testing has largely been abandoned in clinical practice. ${ }^{(49)}$

The lactulose hydrogen breath test serves as a surrogate marker of orocaecal transit times. In this test, oral lactulose passes undigested through the small bowel to the colon, where it undergoes fermentation by colonic bacterial to form shortchain fatty acids, including hydrogen and/or methane gas, which is absorbed systemically and excreted in the breath. Most centres use lactulose $10 \mathrm{~g}$ and a 2- to 4-hour breath sampling period. A positive test is defined as: (a) fasting hydrogen levels $>20$ ppm; (b) the presence of a double peak, where the first peak represents lactulose metabolism by small intestinal bacteria and the second peak corresponds to lactulose reaching the caecum; and (c) early rise in breath hydrogen concentration > 20 ppm. ${ }^{(50,51)}$ Unfortunately, the lactulose hydrogen breath test is associated with significant limitations. The classic double peak is rarely encountered in clinical practice. In most instances, breath tests are unable to distinguish small bowel from colonic metabolism of substrates. ${ }^{(50)}$ Rather, a single peak in breath hydrogen is found, and this may result from fermentation occurring either in the small bowel (in patients with small intestinal bacterial overgrowth) or in patients with IBS-diarrhoea who have an accelerated ileocaecal transit. The sensitivity and specificity of the lactulose breath test are $68 \%$ and $44 \%$, respectively, ${ }^{(52)}$ rendering this test inadequate for routine clinical practice as compared to small bowel culture. Other compounds that have been used for the evaluation of small intestinal bacterial overgrowth, including D-xylose and ${ }^{13} \mathrm{C}$-xylose, have yielded conflicting results. In view of the significant limitations associated with breath tests, they are not recommended for routine clinical use.

Manometry studies of the small bowel (Fig. 7) typically combine antral evaluation with pyloro-duodenal-jejunal motility. This allows for the quantification of contractility in the regions of the GI tract that determine gastric emptying and interdigestive motility. Migrating motor complex (MMC) is the most studied and well-described pattern of GI motor function. Its presence implies proper functioning of complex neuroenteric pathways. ${ }^{(53)}$ However, the invasive nature and high costs involved have largely restricted this diagnostic modality to tertiary referral centres in Europe and North America.

\section{Evaluation of colonic and anorectal function}

Gastroenterologists frequently encounter patients with pelvic floor disorders, which can affect $10 \%-15 \%$ of the population. ${ }^{(54)}$ Disorders of colonic motility typically present with constipation and diarrhoea. In the evaluation of patients with constipation who have not responded to a high-fibre diet or over-the-counter laxatives and after the exclusion of organic causes, colonic transit tests using radio-opaque markers (ROM) can easily be performed. The ROM test is a simple and non-invasive method to differentiate normal transit from slow transit constipation. Although this test measures whole gut transit time (WGTT), it is also used as an estimate of colonic transit time, as most of the WGTT reflects the passage through the colon. ${ }^{(55)}$ Different protocols have been described, including the Hinton ${ }^{(56)}$ and Metcalf ${ }^{(57)}$ techniques. In the former technique, ${ }^{(56)}$ ingestion of a known number of pellets (either 20 or 24) is followed by single abdominal radiography after 120 hours (Day 6). Slow transit is defined by the presence of $\geq 20 \%$ of pellets in the gut.

Anorectal manometry (ARM) provides valuable information on the underlying pathophysiology of constipation in patients who have unexplained constipation that did not respond to laxatives, and dietary and lifestyle measures. It is also useful in patients with faecal incontinence after established diagnostic tests (including endoscopy and stool studies) are unyielding. ${ }^{(58)}$ ARM study involves the insertion of a catheter with pressure sensors and a balloon on the catheter tip. Resting and squeeze pressures and the rectoanal gradient (the difference between rectal and anal pressures) are measured. This is followed by asking the patient to bear down and attempt to defaecate. The rectal balloon is 

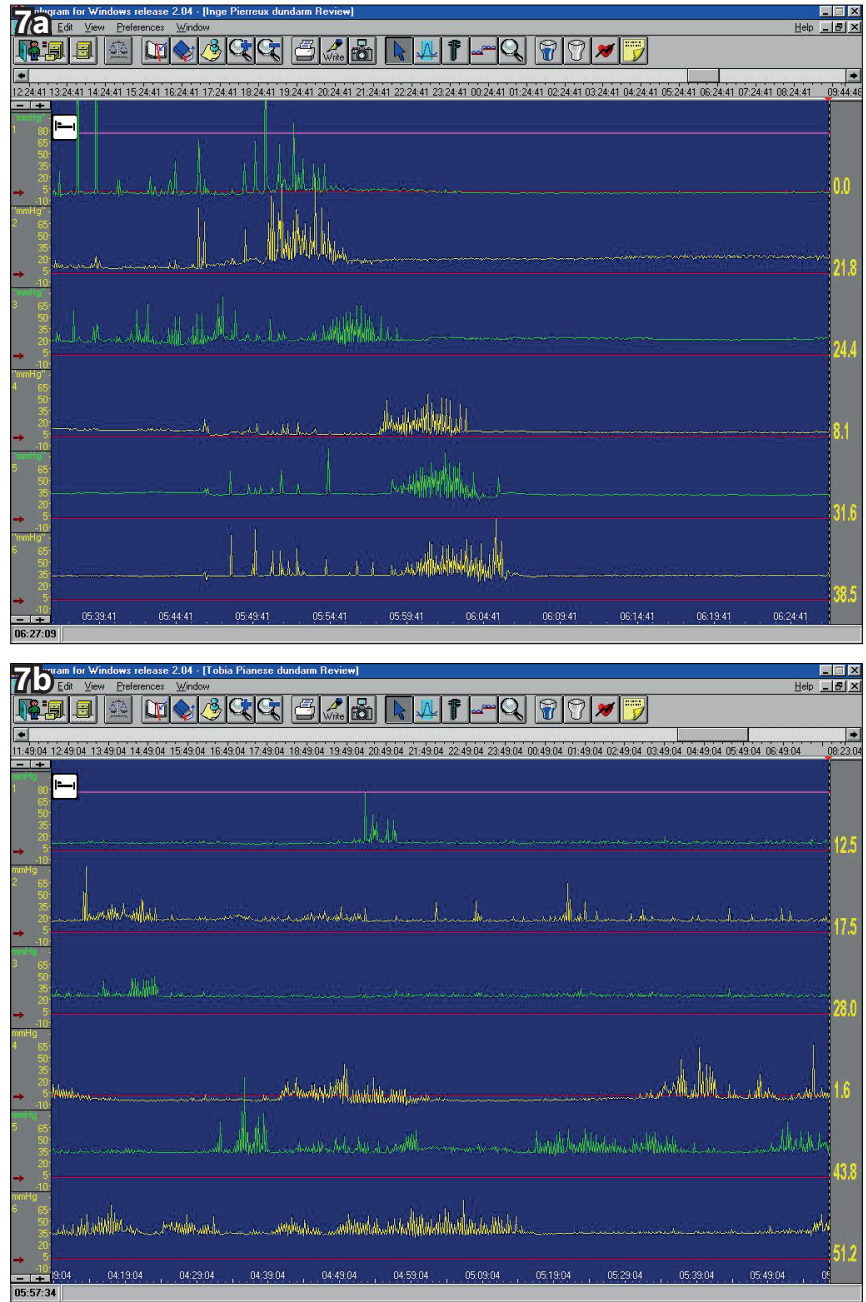

Fig. 7 (a) Antro-pyloro-duodenal jejunal manometry. Example of a norma migrating motor complex (MMC) pattern in the fasting state (night) of a normal subject. The upper 3 recordings are from the antrum-pylorus, the lower 3 recordings are from the duodenum-jejunum. (b) Example of a normal MMC pattern in the fasting state of a patient with enteric neuropathy. In the latter, abnormal neurogenic motor activity is seen with disruption of the normal MMC pattern with abnormal activity fronts, bursts of uncoordinated contractions, and sustained uncoordinated contractions.

subsequently inflated with $30-50 \mathrm{ml}$ of air to evaluate for the rectoanal inhibitory reflex (Fig. 8a). ARM is often combined with the rectal barostat test; the latter involves stepwise and gradual inflation of the balloon and establishing volumes associated with first sensation, discomfort and rectal threshold. ${ }^{(59)}$ In some centres, the rectal balloon expulsion test is included to test the patient's ability to expel a water-filled balloon. ${ }^{(60)}$

Patients who have pelvic floor dyssynergia (Fig. 8b) may manifest a paradoxical rise of anal sphincter pressures, as demonstrated on ARM during attempted defaecation, and may similarly be unable to expel a fluid-filled rectal balloon. Conversely, patients who have faecal incontinence often manifest low resting and squeeze pressures. High-resolution anorectal manometry (HRARM) is progressively being introduced in Singapore. The HRARM catheter (4.2-mm outer diameter) (Sierra Scientific Instruments, Los Angeles, CA, USA) has ten circumferential sensors - eight sensors at 6-mm interval along the anal canal and two sensors in the rectal balloon. At each level, there are 36 circumferentially orientated, pressure-sensing elements that detect pressure using the pressure transducer technology. These 36 sector pressures are averaged to obtain a single value. ${ }^{(61)}$

Despite these technological advances, the inherent limitations of ARM deserve mention. There is considerable overlap in the rectoanal gradient between asymptomatic subjects and patients with pelvic floor dyssnergia. The lack of privacy and the act of artificially simulating rectal evacuation in the left lateral supine position in a laboratory setting may contribute to overlapping results between asymptomatic controls and patients. In addition, there is no single criterion used to diagnose defaecation disorders (DDs). In a recent meta-analysis of 7,591 patients with constipation, the prevalence of findings that suggested abnormal defaecation was varied - from $14.9 \%$ for absent opening of the anorectal angle on defaecography to $47.7 \%$ for a dyssynergic pattern on anorectal manometry and $52.9 \%$ on ultrasonography. ${ }^{(62)}$ These findings highlight the considerable heterogeneity of DDs and their associated challenges. Thus, test results must be interpreted in the overall clinical context, taking into account local facilities and costs. Ultimately, the impact of diagnosing DDs is that it enables the clinician to tailor the appropriate treatment. Treatments such as biofeedback and pelvic floor retraining in patients with DDs have been well established. ${ }^{(11)}$

Defaecography provides valuable information on the anorectum. ${ }^{(63)}$ In this procedure, barium is injected into the rectum, and the patient is asked to expel the volume of barium. Information gained from this modality includes the identification of an enterocoele, rectoanal gradient and pelvic floor descent. To avoid radiation exposure, MR defaecography ${ }^{(64)}$ can be performed; however, this test is not available in Singapore.

\section{Novel diagnostics}

Technological advances now enable us to evaluate patients in an ambulatory setting with minimal interference of daily activities. The wireless Bravo $\mathrm{pH}$ capsule measures oesophageal acid exposure over a prolonged monitoring period. In recent years, the wireless SmartPill system concurrently measures pressure, $\mathrm{pH}$ and temperature, and allows for the evaluation of gastric emptying time, small bowel transit time, colonic transit time and WGTT. This system consists of a wireless motility capsule, data receiver, docking station, computer and data analysis software. The SmartPill capsule $(26.8 \mathrm{~mm} \times 11.7 \mathrm{~mm})$, which contains sensors for $\mathrm{pH}$, temperature and pressure, wirelessly transmits this information at $434 \mathrm{MHz}$ using radiofrequency technology. The SmartPill is approved by the US Food and Drug Administration (FDA) for the measurement of gastric emptying in patients with suspected gastroparesis. ${ }^{(65)}$ It has shown performance characteristics that are comparable to the gastric emptying test ${ }^{(66)}$ and the ROM test ${ }^{(56,57)}$ in the evaluation of WGTT and colonic transit time. More recently, the SmartPill has been compared with conventional ROM in assessing patients with slow transit constipation based on symptoms. Good correlation was observed between the wireless motility capsule and the ROM test $(r=0.718, p=0.0001) .{ }^{(67)}$ The SmartPill has also been directly compared with conventional antroduodenal manometry (ADM) in assessing gastric and small bowel MMCs. In Brun et al's study, ${ }^{(68)}$ healthy subjects underwent insertion of the ADM catheter, and 

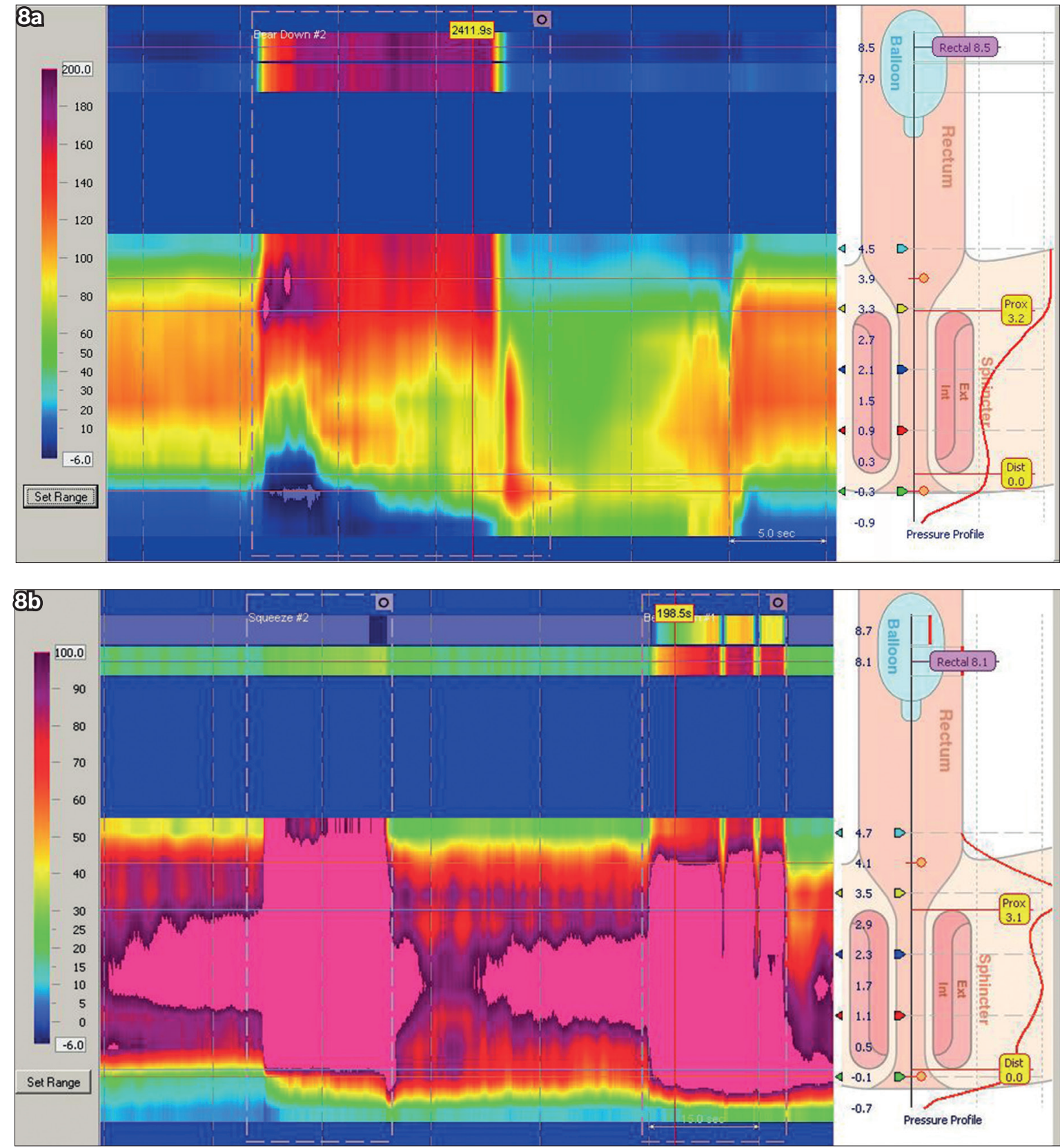

Fig. 8 (a) High-resolution anorectal manometry of a normal bearing-down attempt shows an increase in rectal pressure and a decrease in pressure of the anal sphincter. (b) Anorectal manometry of a patient with obstructed defaecation (pelvic floor dyysnergia) shows paradoxical contraction of the anal sphincter during the bearing-down manoeuvre.

following ingestion of a standard meal, they then swallowed the SmartPill. Using the 10th amplitude percentile contractions as pressure thresholds, the sensitivity and specificity of high amplitude contractions recorded on the SmartPill, which represents phase III MMCs, were respectively $90 \%$ and $72 \%$ in the stomach and $74 \%$ and $85 \%$ in the small bowel, with negative predictive values of $99.9 \%$ in both regions. Thus, the authors concluded that the SmartPill has the potential to serve as a screening tool in patients with suspected small bowel dysmotility. ${ }^{(68)}$

\section{CONCLUSION}

Neurogastroenterology and motility has moved from an obscure niche in academic gastroenterology ${ }^{(69)}$ to an area of intense research. These disorders make up a substantial proportion of clinic visits encountered by the gastroenterologist, and their severity ranged from mild to conditions that significantly impact the affected patients. ${ }^{(70)}$ Measurement techniques are constantly evolving with the times, but one must acknowledge that despite the technical advances made, not all the latest developments have translated into daily clinical practice. The clinical relevance of EGG remains unproven, while the use of complex imaging techniques like 3-dimensional ultrasonography and MR imaging are limited to only a few centres in the world. Thus, when evaluating patients with disordered sensorimotor function, the diagnostic modality used is often guided by local expertise and available facilities. Other factors to consider include the diagnostic specificity of the test, the ability to find a cause for the symptoms experienced, and the ability of the test to influence the choice 
Table III. Summary of functional gastrointestinal (GI) tests available locally.

\begin{tabular}{|c|c|c|}
\hline $\begin{array}{l}\text { Region of } \\
\text { Gl tract }\end{array}$ & $\begin{array}{l}\text { Functional GI tests } \\
\text { available locally }\end{array}$ & $\begin{array}{l}\text { Clinical } \\
\text { utility }\end{array}$ \\
\hline \multirow[t]{4}{*}{ Oesophagus } & $\begin{array}{l}\text { High-resolution } \\
\text { manometry }\end{array}$ & $\begin{array}{l}\text { Simple to perform; evaluation } \\
\text { of dysphagia, persistent reflux, } \\
\text { unexplained chest pain; prior } \\
\text { to anti-reflux surgery }\end{array}$ \\
\hline & $\begin{array}{l}\text { Wireless } \\
\text { oesophageal } \\
\text { pH capsule }\end{array}$ & $\begin{array}{l}\text { Better tolerated than } \\
\text { catheter measurement, but } \\
\text { higher cost }\end{array}$ \\
\hline & $\begin{array}{l}\text { 24-hour pH/ } \\
\text { impedance }\end{array}$ & $\begin{array}{l}\text { Measures both acid and } \\
\text { non-acid reflux; catheter } \\
\text { discomfort }\end{array}$ \\
\hline & 24-hour pH & $\begin{array}{l}\text { Rarely performed, as it } \\
\text { only measures acid reflux; } \\
\text { catheter discomfort }\end{array}$ \\
\hline \multirow[t]{3}{*}{ Gastric } & $\begin{array}{l}\text { Gastric } \\
\text { scintigraphy }\end{array}$ & $\begin{array}{l}\text { Gold standard for evaluation } \\
\text { of abnormal gastric } \\
\text { emptying; involves the use of } \\
\text { radioactive isotopes }\end{array}$ \\
\hline & ${ }^{13} \mathrm{C}$ - breath test & $\begin{array}{l}\text { Simple to perform; } \\
\text { office-based test }\end{array}$ \\
\hline & SmartPill & Not widely available \\
\hline \multirow[t]{2}{*}{ Colon } & Transit markers & Noninvasive; inexpensive \\
\hline & SmartPill & Not widely available \\
\hline $\begin{array}{l}\text { Anorectal } \\
\text { region }\end{array}$ & $\begin{array}{l}\text { Anorectal } \\
\text { manometry }\end{array}$ & $\begin{array}{l}\text { Simple to perform; } \\
\text { inexpensive }\end{array}$ \\
\hline
\end{tabular}

of therapy. ${ }^{(13)}$ Table III summarises the functional Gl tests that are locally available. Measurement techniques that have gained popularity in Singapore include high-resolution oesophageal manometry, combined impedance-pH monitoring and HRARM. More recently, the use of the wireless SmartPill to measure regional transit time and WGTT is gaining increasing acceptance.

The main limitation of functional Gl studies is the lack of diagnostic specificity. Hence, they are best used in the context of providing an explanation for symptoms that persist after exclusion of a structural lesion on endoscopy and radiological imaging. This in turn helps the clinician to tailor the appropriate therapy. In the appropriate clinical setting, the role of functional Gl evaluation lies in providing an explanation for the cause of symptoms, which helps to alleviate patients' concerns, reassuring them that there is no serious underlying organic pathology, as well as guide the gastroenterologist to implement the appropriate therapy. To date, this remains the most important clinical impact of functional Gl evaluation.

\section{REFERENCES}

1. Drossman DA. The functional gastrointestinal disorders and the Rome III process. Gastroenterol 2006; 130:1377-90.

2. Wingate D, Grundy D. Neurogastroenterology and motility: at last, an equal partnership. Neurogastroenterol Motil 2000; 12:1

3. Quigley EM. Gastrointestinal motility: an academic and research perspective. Dig Dis 2006; 24:218-20.

4. Ouyang A, Locke GR 3rd. Overview of neurogastroenterologygastrointestinal motility and functional Gl disorders: classification, prevalence, and epidemiology. Gastorenterol Clin North Am 2007; 36:485-98.

5. Törnblom H, Lindberg G. A 21 st century look at the spectrum of gastrointestinal motility disorders. What is dysmotility; what is functional? Gastroenterol Clin North AM 2011; 40:715-23.

6. Galmiche JP, Clouse RE, Bálint A, et al. Functional esophageal disorders. Gastroenterology 2006; 130:1459-65.

7. Tack J, Talley NJ, Camilleri M, et al. Functional gastroduodenal disorders. Gastroenterology 2006; 130:1466-79.

8. Longstreth GF, Thompson WG, Chey WD, et al. Functional bowel disorders. Gastroenterology 2006; 130:1480-91.

9. Clouse RE, Mayer EA, Aziz Q, et al. Functional abdominal pain syndrome. Gastroenterology 2006; 130:1492-7.

10. Behar J, Corazziari E, Guelrud M, et al. Functional gallbladder and sphincter of oddi disorders. Gastroenterology 2006; 130:1498-509.

11. Bharucha AE, Wald A, Enck P, Rao S. Functional anorectal disorders. Gastroenterology 2006; 130:1510-8.

12. Talley NJ. Functional gastrointestinal disorders as a public health problem. Neurogastroenterol Motil 2008; 20 Suppl 1:121-9.

13. Tack J. Mandatory and optional function tests in gastroduodenal disorders. Best Pract Res Clin Gastroenterol 2009; 23:387-93.

14. Spechler SJ, Castell DO. Classification of oesophageal motility abnormalities. Gut 2001; 49:145-51.

15. Clouse RE, Staiano A. Topography of the esophageal peristaltic pressure wave. Am J Physiol 1991; 261(4 Pt 1):G677-84.

16.Clouse RE, Staiano A, Alrakawi A, Haroian L. Application of topographical methods to clinical esophageal manometry. Am J Gastroenterol 2000; 95:2720-30.

17. Bredenoord AJ, Fox M, Kahrilas $\mathrm{P}$, et al; International High Resolution Manometry Working Group. Chicago classification criteria of esophageal motility disorders defined in high resolution esophageal pressure topography. Neurogastroenterol Motil 2012; 24 Suppl 1:57-65.

18. Pandolfino JE, Kwiatek MA, Nealis T, et al. Achalasia: a new clinically relevant classification by high-resolution manometry. Gastroenterology 2008; 135:1526-33.

19. Rohof WO, Salvador R, Annese V, et al. Outcomes of treatment for achalasia depend on manometric subtype. Gastroenterology 2013; 144:718-25

20. Pandolfino JE, Richter JE, Ours T, et al. Ambulatory esophageal pH monitoring using a wireless system. Am J Gastroenterol 2003; 98:740-9.

21. des Varannes SB, Mion F, Ducrotté $P$, et al. Simultaneous recordings of oesophageal acid exposure with conventional $\mathrm{pH}$ monitoring and a wireless system (Bravo). Gut 2005; 54:1682-6.

22. Sifrim D, Holloway R, Silny J, et al. Acid, nonacid, and gas reflux in patients with gastroesophageal reflux disease during ambulatory 24-hour pH-impedance recordings. Gastroenterology 2001; 120:1588-98.

23. Zentilin P, Dulbecco P, Savarino E, Giannini E, Savarino V. Combined multichannel intraluminal impedance and $\mathrm{pH}$-metry: a novel technique to improve detection of gastro-oesophageal reflux literature review. Dig Liver Dis 2004; 36:565-9.

24. Sifirm D, Dupont L, Blondeau K, et al. Weakly acidic reflux in patients with chronic unexplained cough during 24 hour pressure, $\mathrm{pH}$, and impedance monitoring. Gut 2005; 54:449-54.

25. Zerbib F, Duriez A, Roman S, Capdepont M, Mion F. Determinants of gastro-oesophageal reflux perception in patients with persistent symptoms despite proton pump inhibitors. Gut 2008; 57:156-60.

26. Tutuian R, Vela MF, Hill EG, et al. Characteristics of symptomatic reflux episodes on Acid suppressive therapy. Am J Gastroenterol 2008; 103:1090-6

27. Quigley EM. Non-erosive reflux disease, functional heartburn and gastroesophageal reflux disease; insights into pathophysiology and clinical presentation. Chin J Dig Dis 2006; 7:186-90.

28. Locke GR 3rd. Prevalence, incidence and natural history of dyspepsia and functional dyspepsia. Baillieres Clin Gastroenterol 1998; 12:435-42.

29. Parkman HP, Jones MP. Tests of gastric neuromuscular function. Gastroenterology 2009; 136:1526-43.

30. Abell TL, Camilleri M, Donohoe K, et al; American Neurogastroenterology and Motility Society and the Society of Nuclear Medicine. Consensus recommendations for gastric emptying scintigraphy: a joint report of the American Neurogastroenterology and Motility Society and the Society for Nuclear Medicine. Am J Gastroenterol 2008; 103:753-63.

31. Chey WD, Shapiro B, Zawadski A, Goodman K. Gastric emptying characteristics of a Novel (13) C-octanoate-labeled muffin meal. J Clin Gastroenterol 2001; 32:394-9.

32. Chew CG, Bartholomeusz FD, Bellon M, Chatterton BE. Simultaneous $13 \mathrm{C} / 14 \mathrm{C}$ dual isotope breath test measurement of gastric emptying of solid and liquid in normal subjects and patients: comparison with scintigraphy. Nucl Med Rev Cent East Eur 2003; 6:29-33. 
33. Zahn A, Langhans CD, Hoffner S, et al. Measurement of gastric emptying by $13 \mathrm{C}$-octanoic acid breath test versus scintigraphy in diabetics. Z Gastroenterol 2003; 41:383-90.

34. Camilleri M. Does delayed gastric emptying really cause symptoms in functional dyspepsia? Gut 2006; 55:909-10.

35. Talley NJ, Locke GR 3rd, Tack J. Does delayed gastric emptying really cause symptoms in functional dyspepsia? We still doubt it! Gut 2006; $55: 1674$

36. Kusano M, Zai H, Shimoyama Y, et al. Rapid gastric emptying, rather than delayed gastric emptying, might provoke functional dyspepsia. J Gastroenterol Hepatol 2011; 26 Suppl 3:75-8.

37. Bharucha AE, Manduca A, Lake DS, et al. Gastric motor disturbances in patients with idiopathic rapid gastric emptying. Neurogastroenterol Motil 2011; 23:617-e252.

38. Tack J, Bisschops R. Mechanisms underlying meal-induced symptoms in functional dyspepsia. Gastroenterology 2004; 127:1844-7.

39. Tack J, Piessevaux H, Coulie B, Caenepeel P, Janssens J. Role of impaired gastric accommodation to a meal in functional dyspepsia. Gastroenterology 1998; 115:1346-52.

40. Boeckxstaens GE, Hirsch DP, Kuiken SD, Heisterkamp SH, Tytgat GN. The proximal stomach and postprandial symptoms in functional dyspeptics. Am J Gastroenterol 2002; 97:40-8.

41. Mundt MW, Hausken T, Smout AJ, Samsom M. Relationships between gastric accommodation and gastrointestinal sensations in healthy volunteers. A study using the barostat technique and two- and threedimensional ultrasonography. Dig Dis Sci 2005; 50:1654-60.

42. Stevens JE, Gilja OH, Gentilcore D, et al. Measurement of gastric emptying of a high-nutrient liquid by 3D ultrasonography in diabetic gastroparesis. Neurogastroenterol Motil 2011; 23:220-5; e113-4.

43. Bouras EP, Delgado-Aros S, Camilleri $M$, et al. SPECT imaging of the stomach: comparison with barostat, and effects of sex, age, body mass index, and fundoplication. Single photon emission computed tomography. Gut 2002; 51:781-6.

44. Feinle C, Kunz P, Boesiger P, Fried M, Schwizer W. Scintigraphic validation of a magnetic resonance imaging method to study gastric emptying of a solid meal in humans. Gut 1999; 44:106-11.

45. Parkman HP, Hasler WL, Barnett JL, Eaker EY; American Motility Society Clinical GI Motility Testing Task Force. Electrogastrography: a document prepared by the gastric section of the American Motility Society Clinica GI Motility Testing Task Force. Neurogastroenterol Motil 2003; 15:89-102.

46. Kim MS, Chey WD, Owyang C, Hasler WL. Role of plasma vasopressin as a mediator of nausea and gastric slow wave dysrhythmias in motion sickness. Am J Physiol 1997; 272(4 Pt 1):G853-62.

47. Miller MA, Parkman HP, Urbain JL, et al. Comparison of scintigraphy and lactulose breath hydrogen test for assessment of orocecal transit: lactulose accelerates small bowel transit. Dig Dis Sci 1997; 42:10-8.

48. Newman A. Breath-analysis tests in gastroenterology. Gut 1974; 15:308-23

49. Saad RJ, Chey WD. Breath testing for small intestinal bacterial overgrowth: maximizing test accuracy. Clin Gastroenterol Hepatol 2014; 12:1964-72.

50. Romagnuolo J, Schiller D, Bailey RJ. Using breath tests wisely in a gastroenterology practice: an evidence-based review of indications and pitfalls in interpretation. Am J Gastroenterol 2002; 97:1113-26.

51. Simrén M, Stotzer PO. Use and abuse of hydrogen breath tests. Gut 2006; 55:297-303.
52. Corazza GR, Menozzi MG, Strocchi A, et al. The diagnosis of small bowel bacterial overgrowth. Reliability of jejunal culture and inadequacy of breath hydrogen testing. Gastroenterology 1990; 98:302-9.

53. Husebye $\mathrm{E}$. The patterns of small bowel motility: physiology and implications in organic disease and functional disorders. Neurogastroenterol Motil 1999; 11:141-61.

54. Bharucha AE, Rao SS. An update on anorectal disorders for gastroenterologists. Gastroenterology 2014; 146:37-45.e2.

55. Rao SS, Camilleri M, Hasler WL, et al. Evaluation of gastrointestinal transit in clinical practice: position paper of the American and European Neurogastroenterology and Motility Societies. Neurogastroenterol Motil $2011 ; 23: 8-23$.

56. Hinton JM, Lennard-Jones JE, Young AC. A ne method for studying gut transit times using radioopaque markers. Gut 1969; 10:842-7.

57. Metcalf AM, Phillips SF, Zinsmeister AR, et al. Simplified assessment of segmental colonic transit. Gastroenterology 1987; 92:40-7.

58. Bharucha AE. Anorectal manometry and imaging are necessary in patients with fecal incontinence. Am J Gastroenterol 2006; 101:2679-81.

59. Fox M, Thumshirn M, Fried M, Schwizer W. Barostat measurements of rectal compliance and capacity. Dis Colon Rectum 2006; 49:360-70.

60. Minguez M, Herreros B, Sanchiz V, et al. Predictive value of the balloon expulsion test for excluding the diagnosis of pelvic floor dyssynergia in constipation. Gastroenterology 2004; 126:57-62

61. Bordeianou L, Savitt L, Dursun A. Measurements of pelvic floor dyssynergia: which test result matters? Dis Colon Rectum 2011; 54:60-5.

62. Videlock EJ, Lembo A, Cremonini F. Diagnostic testing for dyssynergic defecation in chronic constipation: meta-analysis. Neurogastroenterol Motil 2013; 25:509-20.

63. Wald A, Caruana BJ, Freimanis MG, Bauman DH, Hinds JP. Contributions of evacuation proctography and anorectal manometry to evaluation of adults with constipation and defecatory difficulty. Dig Dis Sci 1990; 35:481-7.

64. Fletcher JG, Busse RF, Riederer SJ, et al. Magnetic resonance imaging of anatomic and dynamic defects of the pelvic floor in defecatory disorders. Am J Gastroenterol 2003; 98:399-411.

65. Rao SS, Kuo B, McCallum RW, et al. Investigation of colonic and wholegut transit times with wireless motility capsule and radiopaque markers in constipation. Clin Gastroenterol Hepatol 2009; 7:537-44.

66. Kuo B, McCallum RW, Koch KL, et al. Comparison of gastric emptying of a nondigestible capsule to a radio-labelled meal in healthy and gastroparetic subjects. Aliment Pharmacol Ther 2008; 27:186-96.

67. Rao SS, Coss-Adame E, Valestin J, Mysore K. Evaluation of constipation in older adults: radioopaque markers (ROMs) versus wireless motility capsule (WMC). Arch Gerontol Geriatr 2012; 55:289-94

68. Brun R, Michalek W, Surjanhata BC, et al. Comparative analysis of phase III migrating motor complexes in stomach and small bowel using wireless motility capsule and antroduodenal manometry. Neurogastroenterol Motil 2012; 24:332-e165.

69. Wingate DL. A 20-year perspective--from Journal of Gastrointestinal Motility to Neurogastroenterology and Motility. Neurogastroenterol Motil 2008; 20 Suppl 1:1-7.

70. Locke GR 3rd, Zinsmeister AR, Fett SL, Melton LJ 3rd, Talley NJ. Overlap of gastrointestinal symptom complexes in a US community. Neurogastroenterol Motil 2005; 17:29-34. 


\section{SINGAPORE MEDICAL COUNCIL CATEGORY 3B CME PROGRAMME} (Code SMJ 201502A)

Question 1. The approach to a patient with frequent belching includes:
(a) Gastroscopy.
(b) 24-hour pH impedance.
(c) Proton pump inhibitor.
(d) Behavioural therapy.

Question 2. In a patient with prolonged reflux symptoms, the management approach includes:

(a) Reassuring the patient and continuing with proton pump inhibitor therapy.

(b) Gastroscopy.

(c) Functional evaluation with 24-hour $\mathrm{pH}$ impedance.

(d) Esophageal manometry.

Question 3. A 35-year-old Chinese woman has prolonged symptoms of constipation with frequent straining and a sensation of incomplete evacuation. There is no loss of weight, perrectal bleeding or a significant family history. A prior colonoscopy was reported to be normal. She has tried various laxatives without much benefit. Appropriate management for her includes:
(a) Repeat colonoscopy.
(b) Performing a transit makers test.
(c) Referral for anorectal manometry.
(d) Obtaining a detailed psychological history.

Question 4. The following symptom is a Rome III criterion for irritable bowel syndrome:

(a) Recurrent abdominal pain or discomfort on at least 1 day per month in the last 6 months.

(b) Worsening abdominal pain or discomfort with defaecation.

(c) Onset of abdominal pain or discomfort associated with a change in the frequency of stool.

(d) Onset of abdominal pain or discomfort associated with a stable form (appearance) of stool.

Question 5. Regarding lactulose hydrogen breath tests:

(a) They are useful in evaluating patients who may have Helicobacter pylori gastritis.

(b) They are the gold standard for evaluating patients for the presence of small bowel bacterial overgrowth.

(c) A negative study excludes small bowel bacterial overgrowth.

(d) A positive test does not distinguish small bowel bacterial metabolism from colonic metabolism of substrates.

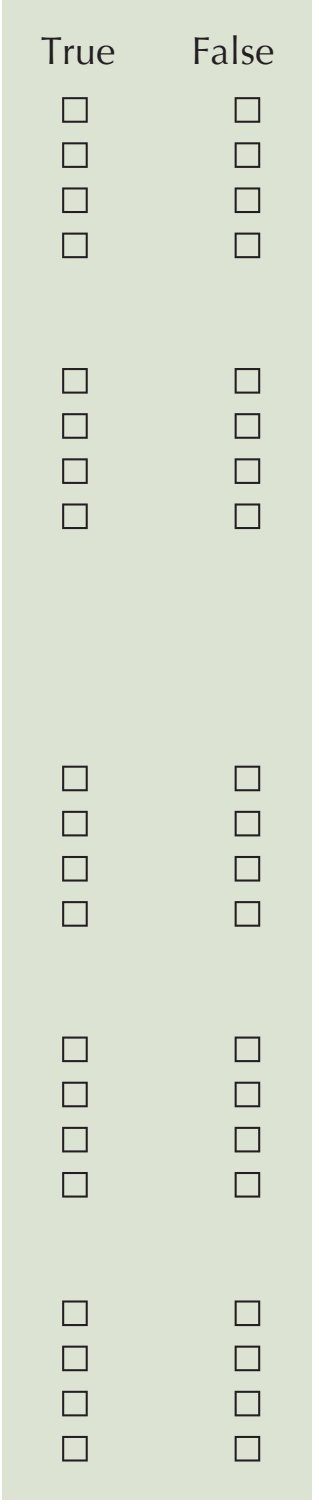

\footnotetext{
Doctor's particulars:

Name in full

MCR number

Specialty:

Email address

SUBMISSION INSTRUCTIONS:

(1) Log on at the SMJ website: http://www.sma.org.sg/publications/smjcurrentissue.aspx and select the appropriate set of questions. (2) Provide your name, email address and MCR number. (3) Select your answers and click "Submit".

RESULTS:

(1) Answers will be published in the SMJ February 2015 issue. (2) The MCR numbers of successful candidates will be posted online at the SMJ website by 6 April 2015. (3) Passing mark is $60 \%$. No mark will be deducted for incorrect answers. (4) The SMJ editorial office will submit the list of successful candidates to the Singapore Medical Council. (5) One CME point is awarded for successful candidates.

Deadline for submission: (February 2015 SMJ 3B CME programme): 12 noon, 27 March 2015.
} 